\title{
A LITERATURE REVIEW ON PLATFORM BUSINESS MODEL: THE IMPACT OF TECHNOLOGICAL PROCESSES ON PLATFORM BUSINESS
}

\author{
Fredrick Oteng Agyeman ${ }^{1}$, Zhiqiang $\mathrm{Ma}^{1}$, Mingxing $\mathrm{Li}^{1}$, \\ Agyemang Kwasi Sampene ${ }^{1}$
}

Jiangsu University, School of Management, No 301 Xuefu Road, Zhenjiang, Jiangsu Province, P. R. China $^{1}$

Corresponding Author: Fredrick Oteng Agyemang ${ }^{1 *}$

Article DOI: https://doi.org/10.36713/epra7300

DOI No: 10.36713/epra7300

\begin{abstract}
With the uprising of China's explosive expansion in the business-to-consumer electronic platform business, it is vital to understand what impact Chinese consumers to shop online. Enabling platform owners to adjust their electronic marketing strategy to successfully adapt to Chinese customers' changing demands and lifestyles and improve their online purchasing experiences and satisfaction is critical for platform growth. This literary works aimed to address the origin of this pattern of offline to online business platforms. The literary works reviewed portrayed that technology has been an indispensable product the Chinese and the world cannot do without it, making an overwhelming acceptance of platform business and strategies. Studies indicate that the platform business and internet use for patronizing products and services become enormous in the early 1990s in China. In addressing the factors that greatly impact the technological process acceptance, individual differences could be considered when describing customers' online purchasing intents in China. Provision for a deeper comprehension of end users' advent of the internet as a shopping and transaction channel while also boosting an electronic platform retailer's market targeting and segmentation efficacy.
\end{abstract}

KEYWORDS: Platform Business, Electronic Business Platform, Technology, online shopping, China.

\section{INTRODUCTION}

Technology refers to the material and nonmaterial structures formed by exerting physical and mental effort to attain the desired outcome. Technology may also be described as a set of techniques, skills, procedures, and processes adopted to manufacture goods or services. Technologies help to accomplish specific objectives and scientific inquiries. Technology encompasses the awareness of techniques, regulations, and other factors incorporated in machines to function without requiring a detailed understanding of how they work. Advanced technologies are the source of inventing platforms. A platform is a value-generating business model that allowing multiple interdependent parties to exchange information, normally consumers and producers (Johansson \& Deniz, 2017). To enable these transactions, platforms leverage and create large, scalable networks of end-users and services that can be accessed on-demand.

Companies must first persuade buyers and sellers to access an empty network to initiate digital services in double-sided markets, which is a significant challenge. The "chicken-and-egg dilemma" describes customers' phenomenon in joining the platform as "No one joins before everybody joins" (Veisdal, 2020). Based on earlier studies, it could be deduced that platform managers and owners need to engage in aggressive monetary procedures for attracting customers to influence potential suppliers to participate (K. J. Boudreau \& Jeppesen, 2015). In existing concepts, the determination of manufacturers of services and goods to join a platform are considered to primary be the role of their visions concerning the standard of involvement on the observed in the markets 
(Fuentelsaz et al., 2015). Platform market studies are primarily concerned with developing strategies to ensure that prospective participants' needs are met (Hagiu \& Spulber, 2013).

\section{LITERARY WORKS}

The growing popularity and general availability of online shopping have prompted extensive research into the factors that impact consumers' online purchasing behavior. The earlier studies aimed to create internet buyer profiles and find predictors of customers' propensity to shop online and their adoption of these systems. Consumer online commitment, online buying contentment, and electronic transaction loyalty have all been the subject of recent research concerning online repurchasing (Massad et al., 2006). (Cheung et al., 2005) gave an essential and extensive evaluation of customers' online attitudes' theories and empirical findings by synthesizing studies from 1994 to 2002. The primary conceptual grounds in the surveyed literature were identified as the theory of reasoned action (TRA), theory of planned behavior (TPB), and technology acceptance model (TAM). Consumer online behaviour is considered to be influenced by five broad types of determinants:

1. Consumer demographics, perceived risk, attitude, motivation, and trust are factors to consider when designing a platform strategy.

2. The product characteristics in connection with price and product is also a key factor.

3. Traders and intermediate attributes such as privacy, brand, service, and security management are the essential characteristics of intermediate qualities.

4. Exposure, market instability, and competition are all factors that influence the platform's business environment.

5. Ease of use and information quality are also essential characteristics that influence platform business.

Meta-analyses have also been used to investigate further the factors influencing customers' decision to purchase online or adopting platform purchasing (Cheung et al., 2005; L. Zhang et al., 2012).

Studies portrayed that in 2010 , China could boast about 420 million internet users, making it the world's most populous country with internet access. Hundreds of millions of individuals have more disposable income. They continue to patronize the service in grand style as their income rises hence creating an enormous advantage for the consumer, platforms, and manufacturers (Lemieux, 2010; Wang et al., 2011).

The widespread availability of the internet in developed and developing countries has resulted in numerous platforms facilitating cross-border trading (Cheung et al., 2005). Internet platforms supported golden Projects in areas such as healthcare and transportation for the industry. In 1994, China's Internet became completely operational, laying the groundwork for electronic business. Jack Ma established 'China Yellow Page,' in 1995, the pioneer internet firm to offer new website technology solutions. China Chemical Network also became the pioneer vertical website provider concentrating on a particular type of internet resources. China's platform company entered the developmental period between its inception and 2000. The pioneer online advertising, the Chinese Goods Ordering System (CGOS) operation within 1997, the pioneer online payment in 1998, and the formal launch of websites for business to customers (B2C) like Ctrip www.8848.com, and Dangdang within 1999 were all highlights of this period. Simultaneously, companies, government agencies, and educational institutions started to enter the internet sector.

Contrarily, when the global dot-com bubble exploded in 2000, some B2C firms, including 8848, went bankrupt. The turbulence was relatively stable from 2000 to 2008. In 2003, Jack Ma formed the Alibaba Group, which launched Taobao (which included T-Mall) and entered the customer-tocustomer (C2C) market. HuiCong was the first Chinese business-to-business electronic network company to be listed on the Hong Kong Stock Exchange's Growing Enterprise Market (GEM). In 2004, JingDong joined the contest. These initiatives lead to the connection of the consumers, platforms, and producers to achieve a common goal (Fisk et al., 2011; Karim, 2020; Kwak et al., 2019). Figure 1 depicts the association of the consumers, platforms, and producers.

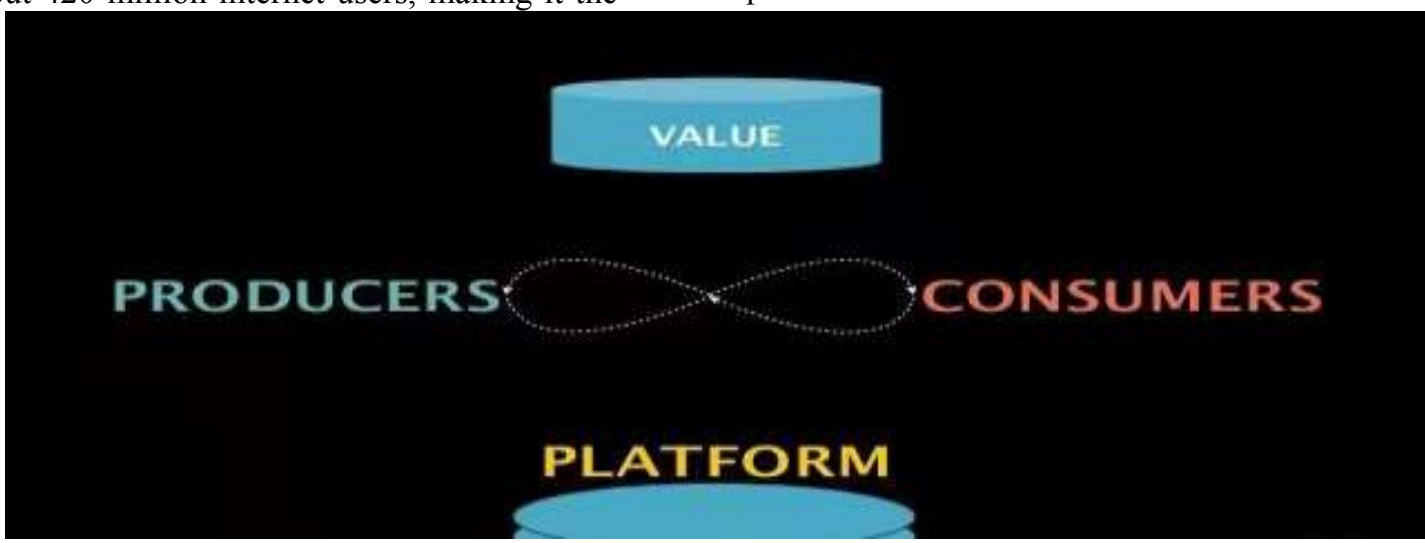

Figure 1 The connection of consumers, platform, and producers. 
Due to the expeditious growth of internet users, platform companies have assumed a new marketing avenue for many companies and people. Platform business' advantages were recognized by "brick and mortar" retailers, who started to add contemporary flair to their websites, signaling that platform business had reached the process of economic sustainability (Applegate et al., 2006; Kotler et al., 2002; Liao et al., 2009; Porter \& Gibbs, 2001; Van Dijck et al., 2018). China's online retail trade reached $\$ 8.3$ billion (56.1 billion yuan in Chinese currency) within 2007 (Hamilton \& Quinlan, 2011; Sonnen et al., 2007). Electronic commerce's profound influence on China's economy is spreading to supply chain connections, 1 online payment, logistics, and different ancillary services. China's ascension into the global spotlight, which coincided with the 2008 Beijing Olympics, was aided by the rise of electronic commerce. For the first time, China's e-population outshine the United States, making it the country with the most Internet users (Barboza, 2008). On November 11, 2009, Alibaba's sales day produced $\$ 7.35$ million (50 million CNY). Alibaba's revenue volume in 2018 surpassed 213.5 billion yuan (approximately 30.7 billion U.S. dollars) within November 12, 2018, during the Alibaba Group's 11.11 Global Shopping Festival in Shanghai, China. However, this was a smaller rise than the 39 percent increase seen in 2017 (D. Zhang, 2017).

China outshines the United States as the world's largest online merchandise market in 2013, attributable to vastly improved convenience, protection, and user-friendliness. China is currently seen as one of the world's platform business leaders. China now accounts for more than $40 \%$ of global electronic commerce transactions, up from $1 \%$ a decade ago. Alibaba Group, Tencent, and JindDong (J.D), among other local Chinese technologists' champions, dominate an increasingly rising electronic commerce ecosystem, mainly within China (Li, 2013; Yang, 2013). Online-to-offline services and electronic business are also common among China's older generations. In addition to a sizable and increasing digital customer base, the industry's rapid growth has resulted in significant domestic and international expansion through extraterritorial trade. China is functioning as a proving ground for innovations that will drive the future of the global electronic platform sector due to its unique climate, accelerating commerce, and digital business improvements. More Chinese people are going abroad to work, learn, and travel than ever before, exposing them to more extraterritorial brands and products. These shoppers use extraterritorial electronic commerce when they get back to their country to buy global developments that are not accessible domestically or are overpriced in local multinational retail establishments in China.
Studies on innovation try to figure out how to promote and build value in this value network between suppliers and customers (Lee \& Schmidt, 2017). A platform strategy is a way of approaching a market in which participants benefit from the engagement of others. According to their willingness to accept payment for a product or service, customers may decide according to their willingness to accept payment for a product or service, as per standard competitive strategy (Montaguti et al., 2002). Platform companies are becoming increasingly important in the development of business value. However, not all platforms are created equal, with some greater possibility of triggering consequential types of increasing returns that will eventually push other platforms out of the market (Brian, 1989; Falque-Pierrotin, 2021).

A platform approach competitively creates value by connecting many dissimilar associated users in multiple markets, and it's probable to increase over time (Veisdal, 2020). A platform strategy is a sophisticated and efficient corporate master plan for conveying creativity and market transactions through a wide range of businesses. Platform innovation and strategy, especially in the information and technology, and mobile sectors, are credited with being the best strategy for achieving sustainable revenue and business transformation (Chugani et al., 2020). Platform supply strategy has reaped huge profits for companies like Tencent, Amazon, Apple, Microsoft, and Google, which have emerged as some of the affluent and most powerful technology companies. These companies are aware of how and when their platforms were made available to the public. Platform developers provide a site for transactions and offer various services and content for cell phones, personal computers, and other electronic devices, regardless of the size of the businesses (Gawer \& Cusumano, 2014).

Numerous researchers have written about the conceptualization of platform strategies and the platform business model (K. Boudreau, 2010; Gawer, 2009; Kim, 2016; Van Alstyne \& Parker, 2017). Platform strategies and platform business represent an essential business innovation model for various industries. Hence diverse definitions have been attributed. Among the earlier definitions widely acknowledged in the study of platform business defined by (Cusumano et al., 1998) stipulates that platforms are a 'group' of subsystems and interfaces.

The availability of internet technology has given organizations, and customers access to vast quantities of data, information, and services, revolutionizing the process of exchanging goods and services online (Dhruv Grewal et al., 2020; Stansberry et al., 2019). Trends in Electronic Business, Electronic Services, and Electronic Commerce have impacted technological processes on goods, services, and business transactions. 
Successfully implementing and managing an electronic business is the hallmark of the countries' development. From the perspective of platforms relating to the product, (Robertson \& Ulrich, 1998) described a platform as a 'cluster of assets.' (Bresnahan \& Greenstein, 1999) indicated that platforms entail a 'bundle of standardized components that connect buyers and sellers. A platform is an architecture of similar specifications that allows "modular replacement of complementary properties," including hardware and software (West, 2003). A platform is a "package" in which headstones and their ecosystems share value (Levin \& Iansiti, 2004).

The way people buy and sell things has changed as a result of the internet. Can you recall how people used to buy plane tickets and hotel reservations over the counter? Electronic business, which was first proposed a few decades ago, has risen to the forefront of significant transactions. It has become so entrenched in citizen's daily lives that the thought of life without it is problematic, if not impossible, for several. Platform business, in reality, accounted for over 15 percent of all retail transactions within China in 2016, with sales totalling $\$ 752$ billion (5.16 trillion CNY) (Klooster, 2017).

Small and medium-sized businesses are the backbone of many economies (European Commission, 2021). Years have gone by and recent years demonstrate that small-scale and medium enterprises' contribution to job creation and economic development is driven by creativity, and innovation has renewed interest. Small and medium-sized businesses currently contribute about 55 percent of Gross domestic products and 65 percent of highincome countries ' employment and over $90 \%$ of middle-income countries ' employment, and $70 \%$ of Gross domestic products (OECD, 1997). Worldwide, small-scale and medium enterprises face increasing competitive pressures, compounded by unfair access to state-of-the-art technologies and scientific resources (OECD, 2017). The reality is that the opportunities created by globalization can only be exploited by a marginal of the global SMEs in the universe.

Modern technology innovators and adapters make up no more than 20 percent of European small and medium-sized enterprises. Retailing businesses and service industries employ fundamental strategies to serve their customers with innovative online and open market technologies (Dhruv Grewal et al., 2017). It is not surprising to witness many firms and industries across the globe keep steadily improving their technology expenditure aimed to attain the set objectives. Many organizations seek cost savings mechanisms through advanced technologies such as robotic production channels, which further decrease labor costs and increase production efficiencies. Small business owners assign a massive amount of expenditure to online, mobile, and social media platforms such as WhatsApp, WeChat with the motive of efficiently and effectively communicating and connecting with customers, which enhances their revenues and mode of payments. Pioneers of new technology have made a tremendous change in trading (D Grewal, 2019). Amazon, for instance, has a host of technological innovation mechanisms aiding trading. Currently, Amazon is actively implementing a drone delivery named Prime Air. Such innovations are the hallmark of unprecedented impact and uncommon results, ginger traders engaging and getting ahead of knowledge dynamics or curves.

Many companies have begun to compete on a global scale as a result of the internet's growth. Entrepreneurs strive to become more successful as their business grows and expands, with the dilemma as to whether by importing or exporting products. Since these are the fundamentals of a successful business, the author outlines some of the most important advantages of platform business in terms of import and export as a result of modern technological processes:

\subsection{Achieving platform business goals through import and export of commodities}

Presently, companies are benefitting greatly from importing and exporting goods across platforms. Importing and exporting will help small and medium businesses grow and expand faster by allowing them to access wider markets outside of their home country and raise income for medium and large enterprises (Robinson, 2018). As companies strive to achieve higher standards in the industry, planning to reduce production costs, importing is unquestionably worthwhile. Otherwise, if a company's local market is insufficient to support its demand and anticipated customers, it would be appropriate to search for new opportunities to expand through export to achieve the desired success. A company's decision to either import or export depends on various goods they are willing to engage in and the target market. Companies constantly seek to identify opportunities and take advantage of them (Rossum, 2017).

\subsection{Enhancing Sales capabilities}

Businesses can save money by importing goods via business platforms. Exporting goods can also result in improved revenue and overall sales potential. Export-oriented companies seek new prospects and extend their vision and markets regionally, domestically, or globally (Osano, 2019).

\subsection{Enhancing Profits}

Exporting goods can help boost profits significantly. Foreign orders, which are typically larger than those placed by local consumers, are the primary reason for shipping goods. Although local buyers may purchase a few items or a pallet, companies from other countries often order a container of goods, resulting in increased profits. 
Furthermore, if your goods are regarded as special or creative in other countries, your earnings will skyrocket in no time (Knight \& Cavusgil, 2004).

\subsection{Knowledge and Experience}

Exporting to international markets provides companies with new knowledge and expertise that can help them discover new products, marketing strategies, and insights into global competitors (Zahra et al., 2012).

\subsection{Future of platform business businesses}

Because of technological advancements and changing customer behavior, the platform business is evolving at a rapid pace. Integration of vast amounts of data and networks is no longer optional; rather, it is a requirement for competition. The direction of the field will be determined by the new strength that emerges. Some of the most recent industrial and trading platforms include virtual or augmented reality, artificial intelligence, robotics, drones, and selfdriving cars classified as the internet of things (Deloitte, 2016). The internet of things should be studied to see how it affects platform business patterns and the function of frontline users (Dhruv Grewal et al., 2017). Smart residences and smart cars are equipped with various intelligent appliances that allow users to perform specific tasks and institutions to schedule future service engagements. Platform's businesses will need to do further research to decide if the internet of things will increase or decrease customer interaction with retailers and service providers, as computers are now in charge of numerous tasks.

As businesses experiment with driverless vehicles, artificial intelligence-based reality, and software improve sensory perceptions. Several distributors and manufacturers are trying to take advantage of drone and robotics technology advancements (Van Doorn et al., 2017). Businesses should learn more about the long-term and short-term benefits and effects of various distribution methodologies through the advanced systems of the platform business.

\section{CONCLUSION}

In summary, emerging platforms business with advanced technology will impact how customers select platforms, select products, and services and make patronage. The offline and online worlds are merging. Identifying what makes these platforms distinct and similar and how emerging technological trends affect both is critical for the future of the platform industry. Customers are probable to gain from innovation by making adequate informed decisions, feeling less rushed, and even increasing their confidence and satisfaction with their choices. Platform businesses must embrace platform business owners' new technologies to make their customers more appealing while also making consumer purchases easier and more convenient. A quest for a way to pursue such a significant field of investigation deserves to be explored further.

Acknowledgments: No funding to declare

\section{REFERENCES}

1. Applegate, L. M., Austin, R. D., \& McFarlan, F. W. (2006). Corporate information strategy and management. McGraw-Hill/Irwin Custom Publishing.

2. Barboza, D. (2008). China Surpasses U.S. in Number of Internet Users. The New York Times. https://www.nytimes.com/2008/07/26/business/w orldbusiness/26internet.html

3. Boudreau, K. (2010). Open platform strategies and innovation: Granting access vs. devolving control. Management Science, 56(10), 18491872.

4. Boudreau, K. J., \& Jeppesen, L. B. (2015). Unpaid crowd complementors: The platform network effect mirage. Strategic Management Journal, 36(12), 1761-1777.

5. Bresnahan, T. F., \& Greenstein, S. (1999). Technological competition and the structure of the computer industry. The Journal of Industrial Economics, 47(1), 1-40.

6. Brian, A. W. (1989). Competing Technologies, Increasing Returns, and Lock-In by Historical Events. The Economic Journal, 99(394), 116-131.

7. Cheung, C. M. K., Chan, G.W.W., \& Limayem, M. (2005). A critical review of online consumer behavior: Empirical research. Journal of Electronic Commerce in Organizations (JECO), 3(4), $1-19$.

8. Chugani, S., Ghosh, S., Greenlee, N., Faste, L., \& Pototschnik, L. (2020). Quickly and Sustainably in Transformations. https://www.bcg.com/capabilities/transformation/ how-to-grow-revenue-quickly-and-sustainablyin-transformations

9. Cusumano, M. A., Nobeoka, K., \& Kentaro, N. (1998). Thinking beyond lean: how multi-project management is transforming product development at Toyota and other companies. Simon and Schuster.

10. Deloitte. (2016). Retail Trends in 2016. https://www2.deloitte.com/jo/en/pages/consumerbusiness/articles/retail-trends-2016.html

11. European-Commission. (2021). Entrepreneurship and Small and medium-sized enterprises (SMEs). European https://ec.europa.eu/growth/smes_en

12. Falque-Pierrotin, A. (2021). What are Network effects and Increasing Returns [Part 1 ]. https://medium.com/samaipata-ventures/thepower-of-increasing-returns-and-nfx-part-1a89efd 4 el $13 b f$

13. Fisk, R. P., Patrício, L., Ordanini, A., Miceli, L., Pizzetti, M., \& Parasuraman, A. (2011). Crowdfunding: transforming customers into investors through innovative service platforms. Journal of Service Management.

14. Fuentelsaz, L., Garrido, E., \& Maicas, J. P. (2015). A strategic approach to network value in 
network industries. Journal of Management, 41(3), 864-892.

15. Gawer, A. (2009). Platform dynamics and strategies: from products to services. Platforms, Markets, and Innovation, 45, 57.

16. Gawer, A., \& Cusumano, M. A. (2014). Industry platforms and ecosystem innovation. Journal of Product Innovation Management, 31(3), 417-433. https://doi.org/10.1111/jpim.12105

17. Grewal, D. (2019). Retail Marketing Management: The 5 Es of Retailing. SAGE Publications.

https://books.google.co.uk/books?id=Lj84uQEA CAAJ

18. Grewal, Dhruv, Hulland, J., Kopalle, P. K., \& Karahanna, E. (2020). The future of technology and marketing: a multidisciplinary perspective. Journal of the Academy of Marketing Science, 48(1), 1-8. https://doi.org/10.1007/s11747-01900711-4

19. Grewal, Dhruv, Roggeveen, A. L., \& Nordfält, J. (2017). The Future of Retailing. Journal of Retailing, $\quad 93(1), \quad$ 1-6. https://doi.org/10.1016/j.jretai.2016.12.008

20. Hagiu, A., \& Spulber, D. (2013). First-party content and coordination in two-sided markets. Management Science, 59(4), 933-949.

21. Hamilton, D. S., \& Quinlan, J. P. (2011). The transatlantic economy. Center for Transatlantic Relations, Paul H. Nitze School of Advanced ....

22. Johansson, M., \& Deniz, S. (2017). Charging Information Services for BEVs-Two Competing and Complementary Business Models. 5th European Battery, Hybrid and Fuel Cell Electric Vehicle Congress.

23. Karim, R. (2020). Consumer Engagement with Retail Brands through Social Media Marketing: A Case Study of Daraz Bangladesh Ltd. North China University of Technology.

24. Kim, J. (2016). The platform business model and strategy: A dynamic analysis of the value chain and platform business.

25. Klooster, M. V. 't. (2017). History of the Future: how China takes over world e-commerce? https://www.1421.consulting/2017/08/how-chinatakes-over-world-e-commercel

26. Knight, G. A., \& Cavusgil, S. T. (2004). Innovation, organizational capabilities, and the born-global firm. 124-141. https://doi.org/10.1057/palgrave.jibs.8400071

27. Kotler, P., Jain, D. C., Jain, D., \& Maesincee, S. (2002). Marketing moves: a new approach to profits, growth, and renewal. Harvard Business Press.

28. Kwak, J., Zhang, Y., \& Yu, J. (2019). Legitimacy building and e-commerce platform development in China: The experience of Alibaba. Technological Forecasting and Social Change, 139, 115-124.

29. Lee, H. L., \& Schmidt, G. (2017). Using Value Chains to Enhance Innovation. Production and Operations Management, 26(4), 617-632. https://doi.org/10.1111/poms.12665

30. Lemieux, G. (2010). Google and Internet Control in China: a Nexus Between Human Rights and Trade? Commission on China. North, 1-83.
31. Levin, R., \& Iansiti, M. (2004). The keystone advantage: What the new dynamics of business ecosystems mean for strategy. Innovation, and Sustainability. Mcgraw-Hill.

32. Li, L. (2013). The path to Made-in-China: How this was done and future prospects. International Journal of Production Economics, 146(1), 4-13.

33. Liao, J., Kickul, J. R., \& Ma, H. (2009). Organizational dynamic capability and innovation: An empirical examination of internet firms. Journal of Small Business Management, 47(3), 263-286.

34. Massad, N., Heckman, R., \& Crowston, K. (2006). Customer satisfaction with electronic service encounters. International Journal of Electronic Commerce, 10(4), 73-104.

35. Montaguti, E., Kuester, S., \& Robertson, T. S. (2002). Entry strategy for radical product innovations: A conceptual model and propositional inventory. International Journal of Research in Marketing, 19(1), 21-42. https://doi.org/10.1016/S0167-8116(02)00046-0

36. OECD. (1997). Small businesses, job creation, and growth: facts, obstacles and best practices 1 . https://www.oecd.org/cfe/smes/2090740.pdf

37. OECD. (2017). Key issues for digital transformation in the G2O. https://www.oecd.org/g20/key-issues-for-digitaltransformation-in-the-g20.pdf

38. Osano, H. M. (2019). Global expansion of SMEs: role of global market strategy for Kenyan SMEs. Journal of Innovation and Entrepreneurship, 8.

39. Porter, M. E., \& Gibbs, M. ilustraciones. (2001). Strategy and the Internet.

40. Robertson, D., \& Ulrich, K. (1998). Planning for product platforms. Sloan Management Review, 39(4), 19.

41. Robinson, J. A. (2018). 14 Reasons Small Businesses Should Start Exporting. International Trade Blog. https://www.shippingsolutions.com/blog/14reasons-small-businesses-should-start-exporting

42. Rossum, J.-E. van. (2017). 5 benefits of international expansion. The Business Journals. https://www.bizjournals.com/bizjournals/howto/growth-strategies/2017/12/5-benefits-ofinternational-expansion.html

43. Sonnen, C. A., Jenness, B., \& McCracken, M. (2007). Economic Effects of Structural Changes in Manufacturing: Retrospective View. Informetrica Limited.

44. Stansberry, K., Anderson, J., \& Rainie, L. (2019). The internet will continue to make life better. Pew Research and Internet \& Technology. https://www.pewresearch.org/internet/2019/10/2 8/4-the-internet-will-continue-to-make-lifebetter/

45. Van Alstyne, M., \& Parker, G. (2017). Platform business: from resources to relationships. NIM Marketing Intelligence Review, 9(1), 24.

46. Van Dijck, J., Poell, T., \& De Waal, M. (2018). The platform society: Public values in a connective world. Oxford University Press.

47. Van Doorn, J., Mende, M., Noble, S. M., Hulland, J., Ostrom, A. L., Grewal, D., \& Petersen, J. A. (2017). Domo Arigato Mr. Roboto: Emergence of 
Automated Social Presence in Organizational Frontlines and Customers' Service Experiences. Journal of Service Research, 20(1), 43-58. https://doi.org/10.1177/1094670516679272

48. Veisdal, J. (2020). The dynamics of entry for digital platforms in two-sided markets : a multicase study. Electronic Market, 30, 539-556.

49. Wang, Y., Norice, G., \& Cranor, L. F. (2011). Who is concerned about what? A study of American, Chinese, and Indian users' privacy concerns on social network sites (Short paper). Lecture Notes in Computer Science (Including Subseries Lecture Notes in Artificial Intelligence and Lecture Notes in Bioinformatics), 6740 LNCS, 146-153. https://doi.org/10.1007/978-3642-21599-5_11

50. West, J. (2003). How open is open enough?: Melding proprietary and open-source platform strategies. Research Policy, 32(7), 1259-1285.

51. Yang, L. (2013). China's Growth Miracle: Past, Present, and Future. United Nation Research Institute for Social Development, 7, 1-17.

52. Zahra, S. A., Ireland, R. D., \& Hitt, M. A. (2012). Expansion by new venture Firms: $I N^{\prime} 1^{\prime}$ TERNATIONAL IN' 1' TERNATIONAL diversity, mode of market entry, technological learning, and performance. Academy of Management Journal, 43(5), 925-950.

53. Zhang, D. (2017). Alibaba Group Generated RMB213.5 Billion (US\$30.8 Billion) of GMV During the 201811.11 Global Shopping Festival. Shanghai- Business Wire). https://www.businesswire.com/news/home/20181 111005051/en/Alibaba-Group-GeneratedRMB213.5-Billion-US30.8-Billion-of-GMVDuring-the-2018-11.11-Global-ShoppingFestival

54. Zhang, L., Zhu, J., \& Liu, Q. (2012). A metaanalysis of mobile commerce adoption and the moderating effect of culture. Computers in Human Behavior, 28(5), 1902-1911. 